As-Syifaa Jurnal Farmasi Desember 2020;12(2):136-143.

ISSN : 2502-9444 (electronic); 2085-4714 (printed)

Journal Homepage : http://jurnal.farmasi.umi.ac.id/index.php/as-syifaa

\title{
ANALISIS KADAR FENOLIK FRAKSI ETIL ASETAT DAUN PETAI CINA (Leucaena leucocephala) (Lam.) de Wit) SECARA SPEKTROFOTOMETRI Uv-Vis
}

\author{
Intan Purnama Sari, Zainal Abidin, St. Maryam
}

Fakultas Farmasi Universitas Muslim Indonesia, Makassar

Email: intanpurnnamasari@yahoo.com

\begin{abstract}
Traditionally, river tamarind leaves (Leucaena leucocephala (Lam.) De Wit.) can be used as medicine for injuries, swollen, diarrhea and also as antiseptic. The river tamarind leaves contains several main compounds such as alkaloids, saponins, flavonoids, phenols, mimosine, lectin, protein, oil, calcium, phosphorus, iron, vitamin $A$ and vitamin $B$. The research aimed to determine the phenolic levels found in the ethyl acetate fraction of the leaves. The extraction was done by maceration method using ethanol $96 \%$ then fractionated with ethyl acetate solvent. The obtained fraction was analysed by UV-Vis spectrophotometry method at the maximum wavelength of $761 \mathrm{~nm}$ using gallic acid as a standard. Based on the qualitative test, river tamarind leaves positively contained phenolic. The phenolic compound contained in the ethyl acetate fraction was $0.176 \mathrm{mgGAE} / \mathrm{g}$ in that every gram of ethyl acetate fraction had phenolic of $0.176 \mathrm{mg}$ equivalent to garlic acid.
\end{abstract}

Key words : Phenolic, Ethyl Acetate Fraction, River Tamarind Leaves (Leucaena leucocephala (Lam.) De Wit.), UV-Vis spectrophotometry.

\section{PENDAHULUAN}

Keanekaragaman tumbuhan Indonesia merupakan kekayaan alam yang patut disyukuri. Tumbuhan merupakan salah satu sumber daya alam yang sangat penting dalam upaya pengobatan dan upaya mempertahankan kesehatan masyarakat. Hingga saat ini menurut perkiraan badan kesehatan dunia (WHO), 80\% penduduk dunia masih menggantungkan dirinya pada pengobatan tradisional termasuk penggunaan obat yang berasal dari tumbuhan.

Secara etnobotani masyarakat Indonesia telah memanfaatkan daun petai cina sebagai obat-obatan diantaranya sebagai obat luka. Penelitian dari Hendra et al., (2011) ${ }^{1}$ menyatakan bahwa daun petai cina mengandung zat aktif berupa alkaloid, saponin, flavonoid, mimosin, lektin, protein, lemak, kalsium, fosfor, zat besi, vitamin A dan vitamin B. Dimana senyawa fenolik di alam terdapat sangat luas mempunyai variasi struktur yang luas, mudah ditemukan di semua tanaman, daun, bunga dan buah. Ribuan senyawa fenolik di alam telah diketahui strukturnya antara lain flavonoid, fenol monosiklik sederhana, fenil propanoid, polifenol (lignin, melanin, tanin), dan kuinon fenolik. Berdasarkan penelitian Sharma et al., (2012) ${ }^{2}$ daun petai cina mengandung senyawa flavonoid dan fenol yang berpotensi sebagai antioksidan.

Komponen fenolik dapat diekstraksi dari bahan tumbuhan dengan menggunakan pelarut polar seperti air, metanol etanol aseton atau pelarut semi polar seperti etil asetat, selain itu berdasarkan uji fitokimia diketahui bahwa fraksi etil asetat mengandung senyawa 
golongan fenolik, flavonoid, alkaloid, dan saponin. ${ }^{1}$

Untuk mengidentifikasi golongan senyawa dapat dilakukan dengan uji warna, penentuan kelarutan, bilangan $\mathrm{Rf}$ dan ciri spektrum $\mathrm{U}^{3}$, salah satu identifikasi yang paling penting dan digunakan secara luas ialah pengukuran spektrum serapan dengan menggunakan spektrofotometer UV-Vis, karena pengukuran ini tidak merusak senyawa dan senyawa dapat dipakai lagi untuk uji-uji yang lain, sehingga analisis kadar fenolik dapat dilakukan dengan menggunakan spektrofotometer UV-Vis.

Berdasarkan uraian di atas perlu dilakukan penelitian lebih lanjut untuk mengetahui kadar fenolik daun petai cina dengan metode spektrofotometri UV-Vis.

\section{METODE PENELITIAN}

\section{Alat dan Bahan}

Adapun alat yang digunakan yaitu mikropipet (Huaweai), timbangan analitik (Sartorius ${ }^{\circledR}$ ), Spektrofotometer UV-Vis (Genesis 10S UV-Vis), Rotary Vacum Evaporator (BUCHI- R-210), dan seperangkat alat maserasi. Adapun bahan yang digunakan yaitu aquadest, asam galat, DMSO, etil asetat, etanol 96\%, Folin Ciocalteu 10\%, fraksi etil asetat daun petai cina (Leucaena leucocephala (Lam.) de Wit.), kertas saring, dan natrium karbonat $7 \%$.

\section{Prosedur Kerja}

\section{Ekstraksi Sampel}

Simplisia daun petai cina (Leucaena leucocephala (Lam) de Wit.) dimasukkan kedalam wadah maserasi sebanyak 100` gram, kemudian ditambahkan dengan etanol 96\% sampai seluruh sampel terendam, kemudian ditutup dan dibiarkan selama 24 jam. Maserat disaring dengan menggunakan kertas saring.
Filtrat diperoleh melalui penyaringan dengan corong buchner, kemudian ampas dimaserasi kembali dengan etanol $96 \%$, sehingga filtrat hampir tidak berwarna. Semua filtrat disatukan dan dipekatkan dengan menggunakan rotavapor sampai tidak ada lagi cairan yang menetes sehingga diperoleh ekstrak etanol daun petai cina (Leucaena leucocephala (Lam) de Wit.). Ekstrak kental daun petai cina (Leucaena leucocephala (Lam) de Wit.) yang didapatkan digunakan untuk dianalisis lebih lanjut. ${ }^{4}$

\section{Fraksinasi Etil Asetat}

Ekstrak etanol $4 \mathrm{~g}$ dilarutkan dengan aquadest $20 \mathrm{~mL}$ kemudian dipartisi dengan 20 $\mathrm{mL}$ pelarut etil asetat dalam corong pisah sebanyak 4 kali dan fraksi etil asetat diuapkan dengan rotavapor sehingga diperoleh fraksi kental etil asetat. ${ }^{5}$

\section{Uji Kualitatif Fenol}

Cara klasik untuk mendeteksi senyawa fenol sederhana ialah menambahkan larutan besi(III) klorida $1 \%$ dalam air atau etanol pada larutan cuplikan menimbulkan warna hijau, merah, ungu, biru, atau hitam yang kuat ${ }^{3}$, hijau kehitaman, dan biru kehitaman. ${ }^{6}$

\section{Uji Kuantitatif Fenol}

Pembuatan reagen $\mathrm{Na}_{2} \mathrm{CO}_{3} 7 \%$ : Pembuatan pereaksi $\mathrm{Na}_{2} \mathrm{CO}_{3} 7 \%, \mathrm{Na}_{2} \mathrm{CO}_{3}$ ditimbang sebanyak 1,75 gram kemudian dilarutkan dengan aquadest hingga $25 \mathrm{~mL}{ }^{7}$

Penentuan panjang gelombang absorbansi maksimum: Sebanyak $0,5 \mathrm{~mL}$ larutan asam galat konsentrasi $70 \mathrm{ppm}$ ditambah $2 \mathrm{~mL}$ reagen Folin Ciocalteau 10\%, kemudian dikocok dan didiamkan selama 5 menit. Ke dalam larutan tersebut ditambah $2 \mathrm{~mL}$ larutan $\mathrm{Na}_{2} \mathrm{CO}_{3} 7 \%$, dikocok hingga homogen, dan diinkubasi pada suhu $45^{\circ} \mathrm{C}$ selama 15 menit, 
Analisis Kadar Fenolik Fraksi Etil Asetat Daun Petai Cina (Leucaena leucocephala) (Lam.) de Wit) Secara Spektrofotometri UV-VIS

kemudian absorbansinya diukur pada panjang gelombang 400-800 nm. ${ }^{8}$

Pembuatan dan pengkuruan larutan standar asam galat

Asam galat ditimbang sebayak $10 \mathrm{mg}$ kemudian dilarutkan dalam $10 \mathrm{~mL}$ DMSO sehingga diperoleh larutan asam galat dengan konsentrasi 1000 ppm. Dari larutan stok dipipet sebanyak $1 \mathrm{~mL}$ dan dicukupkan volumenya hingga $10 \mathrm{~mL}$ dengan DMSO hingga diperoleh konsentrasi $100 \mathrm{ppm}$. Dari larutan tersebut dibuat beberapa seri konsentrasi yaitu 20 ppm, 30 ppm, 40 ppm, 50 ppm, 60 ppm dan 70 ppm, dari masing-masing konsentrasi dipipet $0,5 \mathrm{~mL}$ larutan asam galat, $2 \mathrm{~mL}$ reagen folin ciocalteu $10 \%$ setelah itu campuran tersebut didiamkan selama 5 menit kemudian ditambahkan $2 \mathrm{~mL}$ $\mathrm{Na}_{2} \mathrm{CO}_{3} 7 \%$. Blanko disiapkan bersamaan, yang mengandung $0,5 \mathrm{~mL}$ DMSO, $2 \mathrm{~mL}$ reagen Folin Ciocalteu 10\%, dan $2 \mathrm{~mL} \mathrm{Na}_{2} \mathrm{CO}_{3} 7 \%$. Setelah itu diikubasi pada suhu $45^{\circ} \mathrm{C}$ selama 15 menit. Absorbansi ditentukan menggunakan spektrofotometer pada panjang gelombang 761 nm. ${ }^{9}$
Pembuatan larutan fraksi etil asetat Daun Petai Cina (Leucaena leucocephala (Lam.) de Wit.)

Ditimbang fraksi etil asetat daun petai cina (Leucaena leucocephala (Lam.) de Wit.) sebanyak $10 \mathrm{mg}$ kemudian dilarutkan dengan $10 \mathrm{~mL}$ DMSO, kemudian diencerkan menjadi 200 ppm dan dibuat 3 replikasi. ${ }^{10}$

Penentuan kadar fenolik fraksi etil asetat daun petai cina (Leucaena leucocephala (Lam.) de Wit.)

Larutan fraksi etil asetat konsentrasi 200 ppm dipipet sebanyak $0,5 \mathrm{~mL}$ dimasukkan kedalam vial, ditambahkan $2 \mathrm{~mL}$ reagen folin ciocalteau $10 \%$ setelah itu campuran tersebut didiamkan selama 5 menit kemudian ditambahkan larutan $\mathrm{Na}_{2} \mathrm{CO}_{3} 7 \%$ sebanyak 2 $\mathrm{mL}$. Campuran diinkubasi pada suhu $45^{\circ} \mathrm{C}$ selama 15 menit. Absorbansi larutan ekstrak dibaca pada panjang Absorbansi larutan ekstrak di baca pada panjang gelombang maksimum $761 \mathrm{~nm}$ dengan spektrofotometer UV-Vis. Dilakukan 3 kali pengulangan. Hasilnya dinyatakan sebagai mg asam galat/ gram fraksi. ${ }^{8}$

\section{HASIL DAN PEMBAHASAN}

Tabel 1. Perhitungan rendamen ektrak rendamen etanol sampel daun petai cina (Leucaena leucocephala (Lam.) de Wit).

\begin{tabular}{cccc}
\hline Sampel & Berat sampel $(\mathbf{g})$ & Berat ekstrak $(\mathbf{g})$ & Rendamen ekstrak etanol (\%) b/b \\
\hline Daun petai cina & $100 \mathrm{gram}$ & $9,011 \mathrm{gram}$ & $9,011 \%$ \\
\hline
\end{tabular}

Tabel 2. Perhitungan rendamen fraksi etil asetat sampel daun petai cina (Leucaena leucocephala (Lam.) de Wit)

\begin{tabular}{ccccc}
\hline $\begin{array}{c}\text { Jenis } \\
\text { pelarut }\end{array}$ & Jumlah pelarut $(\mathbf{m L})$ & Berat ekstrak $(\mathbf{g})$ & Berat fraksi $(\mathbf{g})$ & Rendamen $(\%)$ \\
\hline Etil Asetat & $80 \mathrm{~mL}$ & $4,013 \mathrm{gram}$ & $1,289 \mathrm{gram}$ & $32,120 \%$ \\
\hline
\end{tabular}


Analisis Kadar Fenolik Fraksi Etil Asetat Daun Petai Cina (Leucaena leucocephala) (Lam.) de Wit) Secara Spektrofotometri UV-VIS

Tabel 3. Hasil uji kualitatif senyawa fenolik fraksi etil asetat daun petai cina (Leucaena leucocephala (Lam.) de Wit.

\begin{tabular}{ccccc}
\hline Sampel & ${\text { Uji fenolik } \mathrm{FeCl}_{3}}$ & Hasil pengamatan & Pereaksi & Teori Harborne 1987 \\
\hline $\begin{array}{c}\text { Fraksi etil asetat } \\
\text { daun petai cina }\end{array}$ & Biru kehitaman & + & $\mathrm{FeCl}_{3}$ & $\begin{array}{c}\text { hijau, merah, ungu, } \\
\text { biru atau hitam }\end{array}$ \\
\hline
\end{tabular}

Tabel 4. Kadar fenolik fraksi etil asetat daun petai cina (Leucaena leucocephala (Lam.) de Wit)

\begin{tabular}{ccccc}
\hline Replikasi & $\begin{array}{c}\text { Absorbansi } \\
(\mathbf{Y})\end{array}$ & $\begin{array}{c}\text { Kandungan fenol } \\
\text { awal (mg/L) }\end{array}$ & $\begin{array}{c}\text { Kandungan fenol } \\
\text { (mgGAE/g fraksi) }\end{array}$ & $\begin{array}{c}\text { Rata-rata kandungan } \\
\text { fenol (mgGAE/g fraksi) }\end{array}$ \\
\hline 1 & 0,371 & 35,701 & 0,176 & \\
2 & 0,378 & 36,505 & 0,180 & $0,176 \mathrm{mgGAE} / \mathrm{g}$ \\
3 & 0,364 & 34,896 & 0,172 & \\
\hline
\end{tabular}

\section{PEMBAHASAN}

Tanaman petai cina (Leucaena leucocephala (Lam.) de Wit) merupakan tanaman yang banyak dimanfaatkan secara empiris. Tanaman petai cina (Leucaena leucocephala (Lam.) de Wit) memiliki kandungan senyawa alkaloid, saponin, flavonoid, mimosin, lektin, protein, lemak, kalsium, fosfor, zat besi, vitamin A dan vitamin B. ${ }^{1}$ Kandungan lain yang dimiliki oleh tanaman ini yaitu senyawa fenol. ${ }^{2}$ Fenol atau asam karbolat merupakan senyawa dengan gugus hidroksil yang terikat pada cincin aromatik. Senyawa fenolik cukup luas penggunaannya saat ini. Kemampuannya sebagai senyawa biologi aktif memberikan suatu peran yang besar terhadap kepentingan manusia. Salah satunya sebagai antioksidan untuk pencegahan dan pengobatan penyakit degeneratif, kanker, penuaan dini, dan gangguan sistem imun tubuh. ${ }^{11}$ Dalam penenlitian lain disebutkan bahwa efek antiinflamasi dari suatu tanaman disebabkan karena kandungan flavonoid dan fenol didalamnya ${ }^{1}$ sehingga mengingat pentingnya fungsi senyawa fenolik maka penelitian kadar fenolik total yang terkandung dalam tanaman petai cina (Leucaena leucocephala (Lam.) de Wit) perlu dilakukan.

Sampel daun petai cina (Leucaena leucocephala (Lam.) de Wit) diperoleh dari Kabupaten Merauke (Papua). Penanganan sampel dilakukan dengan cara pengumpulan dan pemisahan daun. Kemudian dilakukan sortasi basah dan pencucian. Setelah bersih, daun petai cina tersebut dikeringkan dengan cara diangin-anginkan pada udara terbuka dan terhindar dari sinar matahari langsung. Kemudian diserbukkan dengan tujuan untuk memperluas permukaan simplisia yang berkontak dengan cairan penyari sehingga mempermudah pada proses pengekstraksian. Menurut hasil penelitian Guo et al. 2012 ${ }^{12}$, kandungan total fenol pada ekstrak semakin tinggi seiring dengan semakin kecilnya ukuran partikel. Hal ini mengindikasikan bahwa ukuran partikel membatasi proses difusi pelarut ke dalam partikel dan proses difusi bahan terlarut keluar dari bahan selama proses ekstraksi berlangsung Sampel yang telah diserbukkan kemudian ditimbang kembali berat serbuk, berat sampel serbuk yang diperoleh untuk daun yaitu $100 \mathrm{~g}$. Proses ekstraksi dilakukan dengan melarutkan serbuk kering sebanyak $100 \mathrm{~g}$ 
Analisis Kadar Fenolik Fraksi Etil Asetat Daun Petai Cina (Leucaena leucocephala) (Lam.) de Wit) Secara Spektrofotometri UV-VIS

dengan etanol $96 \%$ sampai seluruh sampel terendam, kemudian ditutup dan dibiarkan selama 24 jam.

$$
\text { Maserat disaring dengan }
$$

menggunakan kertas saring, filtrat diperoleh melalui penyaringan dengan corong buchner kemudian ampas dimaserasi kembali dengan etanol 96\%, sehingga filtrat hampir tidak berwarna, setelah itu filtrat disatukan dan dipekatkan dengan menggunakan rotavapor sehingga diperoleh ekstrak etanol daun petai cina (Leucaena leucocephala (Lam.) de Wit).

Metode ekstraksi yang digunakan dalam penelitian ini adalah maserasi yang merupakan metode ekstraksi yang paling sederhana. Metode ekstraksi maserasi adalah proses pengekstrakan simplisia dengan menggunakan pelarut dengan beberapa kali pengadukan pada suhu ruang. Pemilihan metode ekstraksi maserasi karena mempunyai keuntungan dibandingkan metode ekstraksi lainnya. Keuntungan utama metode esktraksi maserasi yaitu prosedur dan peralatan yang digunakan sederhana juga proses dilakukan tanpa pemanasan sehingga senyawa yang terkandung dalam tanaman tidak terurai dengan pertimbangan bahwa fenolik mengalami penurunan persen kadar jika dipanaskan pada suhu lebih dari $60^{\circ} \mathrm{C} .{ }^{13}$ Kecenderungan kelarutan senyawa golongan fenolik dijelaskan dengan stereokimia fenol dan dan gaya antarmolekul (terutama ikatan hidrogen) yang terjadi antara fenol dan pelarut. Secara khusus, gugus hidroksil pada fenol dapat memperkuat ikatan hidrogen dengan oksigen elektronegatif dari etanol, metanol atau aseton $^{14}$ sehingga digunakan etanol 96\% sebagai pelarut untuk menarik senyawa fenol. Setelah proses ekstraksi ekstrak cair kemudian dikumpulkan lalu diuapkan dengan menggunakan alat rotavapor (rotary vacum evaporator) dengan tujuan untuk mendapatkan ekstrak etanol kental daun petai cina (Leucaena leucocephala (Lam.) de Wit). Ekstrak kental etanol yang diperoleh sebanyak rata-rata $9,011 \mathrm{~g}$ dengan persen rendemen sekitar $9,011 \%$ dilakukan perhitungan persen rendamen ekstrak untuk mengetahui fenol yang ditarik oleh pelarut.

Kecilnya nilai rendemen yang dihasilkan dapat dimungkinkan oleh beberapa faktor, yaitu metode ekstraksi yang digunakan, ukuran partikel sampel, kondisi dan waktu penyimpanan, lama waktu ekstraksi, perbandingan jumlah sampel terhadap jumlah pelarut yang digunakan dan jenis pelarut yang digunakan. ${ }^{15}$ Partisi pada ekstrak etanol daun petai cina bertujuan untuk memisahkan senyawa berdasarkan kelarutannya terhadap pelarut dengan tingkat kepolaran yang berbeda. Partisi dilakukan dengan pelarut air dan etil asetat. Senyawa polar yang berada pada ekstrak etanol akan terdistribusi ke dalam pelarut air dan senyawa yang bersifat kepolarannya rendah akan terekstrak pada pelarut etil asetat. Hasil fraksi yang diperoleh rata-rata adalah $1,289 \mathrm{~g}$ dengan persen ratarata dapat dilhat pada tabel 2 .

Penentuan kadar senyawa pada suatu tumbuhan baiknya diawali dengan pengujian kualitatif untuk mengetahui ada tidaknya kandungan senyawa yang akan diukur. Pengujian kualitatif fenol dilakukan dengan menambahkan $\mathrm{FeCl}_{3}$ pada larutan fraksi etil asetat daun petai cina. Penambahan $\mathrm{FeCl}_{3}$ menyebabkan polifenol mampu mereduksi besi (III) menjadi besi (II). Hal ini juga merupakan cara klasik untuk mendeteksi senyawa fenol, yaitu dengan menambahkan larutan besi(III) klorida $1 \%$ dalam air atau etanol pada larutan 
cuplikan menimbulkan warna hijau kehitaman, dan biru kehitaman. ${ }^{6}$

Berdasarkan uji kualitatif yang
didapatkan bahwa penambahan $\mathrm{FeCl}_{3}$
menyebabkan perubahan warna biru
kehitaman pada sampel, sehingga dapat disimpulkan bahwa fraksi etil asetat daun petai cina mengandung fenol. Hasil pengujian dapat dilihat pada tabel 3. Pada pengukuran kadar fenol dilakukan dengan menggunakan metode Spektrofotometri UV-Vis karena metode ini cocok digunakan dalam menentukan kadar golongan senyawa, selain itu panjang gelombang dari fenol berada pada daerah visible yaitu 400-800 nm. Pengukuran menggunakan Spektrofotometer UV-Vis membutuhkan sampel yang dapat terlarut sempurna dengan reagen Folin-Ciocalteu dan larutan $\mathrm{Na}_{2} \mathrm{CO}_{3}$. Sampel daun petai cina digunakan secara langsung tidak dapat terlarut sempurna, sehingga dilakukan penarikan senyawa fenol dengan fraksinasi ${ }^{16}$ campuran yang tidak sempurna akan menyebabkan kurang akuratnya hasil absorbansi yang diperoleh. Hasil fraksinasi fase etil asetat dipisahkan untuk penetapan kadar fenol.

Penentuan panjang gelombang dilakukan dengan cara melakukan scanning terhadap larutan standar pada daerah visible (400 - $800 \mathrm{~nm}$ ) kemudian diperoleh panjang gelombang maksimal $761 \mathrm{~nm}$. Panjang gelombang maksimal adalah panjang gelombang yang menghasilkan absorbansi tertinggi. Asam galat digunakan sebagai standar dengan seri konsentrasi 20 ppm, 30 ppm, 40 ppm, 50 ppm, 60 ppm, 70 ppm. Kurva kalibrasi asam galat digunakan untuk menentukan kadar senyawa fenolat yang terkandung dalam sampel melalui persamaan regresi dan dinyatakan dalam satuan $\mathrm{mg}$ setara asam galat/g fraksi (mgGAE/g fraksi). Digunakan asam galat sebagai larutan standar karena merupakan salah satu fenol alami dan stabil, serta relatif murah dibanding lainnya. Asam galat termasuk dalam senyawa fenolik turunan asam hidroksibenzoat yang tergolong asam fenol sederhana. Asam galat menjadi pilihan sebagai standar ketersediaan substansi yang stabil dan murni. Asam galat direaksikan dengan reagen Folin-Ciocalteu menghasilkan warna kuning yang menandakan bahwa adanya keberadaan fenol, setelah itu ditambahkan dengan larutan $\mathrm{Na}_{2} \mathrm{CO}_{3}$ menghasilkan warna biru. Senyawa fenolik bereaksi dengan reagen Folin-Ciocalteu hanya dalam suasana basa agar terjadi disosiasi proton pada senyawa fenolik menjadi ion fenolat, sehingga ditambahkan larutan $\mathrm{Na}_{2} \mathrm{CO}_{3}{ }^{11}$ Proses inkubasi dilakukan agar zat bereaksi sempurna dan menghasilkan absorban yang stabil, pemanasan pada suhu $45^{\circ} \mathrm{C}$ akan mempercepat terjadinya reaksi. Proses inkubasi pada suhu ruang membutuhkan waktu selama 2 jam agar semua zat bereaksi dengan sempurna namun kenaikan suhu mampu mengurangi penggunaan waktu inkubasi dengan memperhatikan suhu kestabilan fenol yaitu tidak lebih dari $60^{\circ} \mathrm{C}$, sehingga pemanasan yang dilakukan selama 15 menit pada suhu $45^{\circ} \mathrm{C}$. Persamaan kurva kalibrasi diperoleh dengan persamaan $y=a+b x$ dengan hubungan linear absorbansi dan konsentrasi.

Berdasarkan persamaan regresi untuk absorbansi asam galat pada konsentrasi 20, $30,40,50,60$ dan 70 ppm sebesar $y=0,0087 x$ $+0,0604$. Larutan standar senyawa fenol diperoleh hubungan yang linear antara absorbansi dengan konsentrasi. Pada pengukuran absorbansi yang ditunjukkan 
dengan nilai koefisien korelasi ( $r$ ) sebesar 0,9982, nilai ( $r$ ) ini mendekati angka 1 yang menunjukkan bahwa persamaan regresi tersebut adalah linear, hal ini mendasari bahwa kurva kalibrasi dapat digunakan sebagai pembanding dalam penetapan kadar fenolik total pada sampel petai cina (Leucaena leucocephala (Lam.) de Wit). Pada pengukuran senyawa fenolik dibuat tiga replikasi untuk keperluan akurasi data. Data dari tiga replikasi dapat diamati pada tabel 4.

Berdasarkan tabel tersebut diperoleh kadar fenolik fraksi etil asetat daun petai cina adalah rata-rata sebesar $0,176 \mathrm{mgGAE} / \mathrm{g}$ yang artinya dalam setiap gram fraksi etil asetat daun petai cina (Leucaena leucocephala (Lam.) de Wit) mengandung fenolik 0,176 mg yang setara dengan asam galat.

\section{KESIMPULAN}

Berdasarkan penelitian yang telah dilakukan dapat disimpulkan bahwa fraksi etil asetat daun petai cina (Leucaena leucocephala (Lam) de Wit.) memiliki kandungan senyawa fenol sebesar 0,176 mgGAE/ g fraksi.

\section{DAFTAR PUSTAKA}

1. Hendra R, Ahmad S, Sukari A, Shukor MY, Oskoueian E. Flavonoid analyses and antimicrobial activity of various parts of Phaleria macrocarpa (Scheff.) Boerl fruit. Int J Mol Sci. 2011; 12(6):3422-31.

2. Srivastava N, Chauhan AS, Sharma B. Isolation and Characterization of Some Phytochemicals from Indian Traditional Plants. Biotechnol Res Int. 2012.

3. Harborne JB. Phytochemical Methods A Guide To Modern Tecniques Of Plant Analysis, Third Edition. Chapman Hall. 1998.

4. Gustandy M, Soegihardjo CJ. Uji Aktivitas Antioksidan Menggunakan Radikal 1,1Difenil-2- Pikrilhidrazil dan Penetapan Kandungan Fenolik Total Fraksi Etil Asetat Ekstrak Etanol Buah Anggur Bali (Vitis vinifera L.). J Farm Sains dan Komunitas. 2013;10(2):109-120.
5. Ritna A, Anam S, Khumaidi A. Identifikasi Senyawa Flavonoid Pada Fraksi Etil Asetat Benalu Batu (Begonia Sp.) Asal Kabupaten Morowali Utara. J Farm Galen (Galenika J Pharmacy). 2016;2(2):83-89.

6. Sovia S, Andayani NGPS, Prawishanti IGAR, Ermawan R, Pintaningrum Y. Acute lower limb ischaemia in patient with definite infective endocarditis. Eur Hear Journal, Suppl. 2017.

7. Ahmad AR, Juwita J, Ratulangi SAD. Penetapan Kadar Fenolik dan Flavonoid Total Ekstrak Metanol Buah dan Daun Patikala (Etlingera elatior (Jack) R.M.SM). Pharm Sci Res. 2015; 2(1):1-10.

8. Lestari ARA, Syahfitri SA, Cahyo ST, Wardaniati I, Herli MA. Aktivitas Antibakteri Seduhan Biji Pepaya (Carica papaya L) Terhadap Escherichia coli, Salmonella thypi dan Staphlycocus aureus. Journal Pharm Sci. 2018;1(2):40-45.

9. Stanković M. Total phenolic content, flavonoid concentration and antioxidant activity of Marrubium peregrinum $\mathrm{L}$. extracts. Kragujev J Sci. 2011; 33:63-72.

10. Alfian R, Susanti H. Penetapan Kadar Fenolik Total Ekstrak Metanol Kelopak Bunga Rosella Merah (Hibiscus sabdariffa Linn) dengan Variasi Tempat Tumbuh Secara Spektrofotometri. Pharmaciana. 2012;2(1):73 - 80 .

11. Apsari PA, Sari DNE, Kusuma AP, Indrati O. Effervescent Tablet Formulation Melinjo Seed Extract (Gnetum gnemon L.) Using PEG 6000 As Lubricant and Citric Acid Tartaric Acids As Acid Sources. J EKSAKTA. 2018;18(1):30-41.

12. Liu GL, Guo HH, Sun YM. Optimization of the extraction of anthocyanins from the fruit skin of rhodomyrtus tomentosa (Ait.) hassk and identification of anthocyanins in the extract using high-performance liquid chromatography-electrospray ionizationmass spectrometry (HPLC-ESI-MS). Int J Mol Sci. 2012; 13(5):6292-302

13. Purbowati ISM, Syamsu K, Warsiki E, Sri H. Stabilitas Senyawa Fenolik Dalam Ekstrak Dan Nanokapsul Kelopak Bunga Rosella Pada Berbagai Variasi pH, Suhu dan Waktu. Agrointek. 2016;10(1):31-40. 
Analisis Kadar Fenolik Fraksi Etil Asetat Daun Petai Cina (Leucaena leucocephala) (Lam.) de Wit) Secara Spektrofotometri UV-VIS

14. Dai J, Mumper RJ. Plant phenolics: Extraction, analysis and their antioxidant and anticancer properties. Molecules. 2010.

15. Salamah E, Ayuningrat E, Purwaningsih S. Penapisan awal komponen bioaktif dari kijing taiwan (Anodonta woodiana Lea.)
Sebagai Senyawa Antioksidan. Bul Teknol Has Perikan. 2008;11(2):119-133.

16. Fuentes E, Báez ME, Bravo M, Cid C, Labra F. Determination of Total Phenolic Content in Olive Oil Samples by UV-visible Spectrometry and Multivariate Calibration. Food Anal Methods. 2012; 5(6):1311-1319. 